\title{
The Impact of Macroeconomic Variables on Stock Price Change Percentage for the ESG Listed Companies in Egypt
}

\author{
Aly Saad Mohamed Dawood ${ }^{1}$, Mimi Akkad ${ }^{2}$, Nada Samir ${ }^{3}$, Mahmoud Hussein ${ }^{4}$, Amira Ibrahim ${ }^{5}$ and \\ Bahy Mohamed ${ }^{6}$ \\ 1, Associate Professor of Business Administration Sadat Academy for Management Sciences seconded to \\ Heliopolis University for Sustainable Development, Faculty of Business Administration and Economics, \\ Business Administration Department. \\ 2,3,4,5 and 6Bachelors of Business Administration, Major: Finance and Investment. \\ Heliopolis University for Sustainable Development
}

\begin{abstract}
This study was conducted to see the impact of macroeconomic factors, Gross domestic product, interest rate, inflation rate, money supply and the exchange rate on stock price change percentage of the ESG listed companies according to the approach of Arbitrage Pricing Theory (APT). The data used in this research is secondary data from the central bank of Egypt and the Egyptian Stock Exchange. the total sample of this research are 20 out of 30 companies listed in The Egyptian Stock Exchange (EGX) for the period from 2016 to 2020. The analysis technique used descriptive statistics, correlation matrix and multi regression analysis. The results showed that macroeconomic factors especially interest rate and inflation have a significant negative impact on stock price changes of EGX30 ESG (Environment, Social and Governance) companies with a lower effect than traditional companies where their regression analysis showed percentage exceeding ours (16\%). (Rageb, 2018) (Awd, 2015)

Our main recommendation that all the companies within Egypt have to work hard to transform towards the ESG practices as from the results we have investigated it has low level of risks.
\end{abstract}

Keywords: Macroeconomic variables, Environment Social and Governance, Arbitrage Pricing Theory, Egypt.

\section{Introduction}

The economy develops over time depending on its structure, policies and organizations, all of which are matter to broad historical changes. Unexpectedly, the business cycle did not change, as what happened during the Great shrinkage of the 1930s and the post-Depression repairs, in response to such long-term developments the extension of government and private sector industries, the development of fiscal and other built-in stabilizers, and the great use and role of discretionary macroeconomic. (R. 1. Gordon 1986). Macroeconomic variables are one of the major determinants of a country to measure its economic development. Stakeholders need information of the development of economic factors with the aim to make decisions related to economic policies such as fiscal and monetary policies, the movement of foreign exchange rates, stock movements and other economic policies. Many studies, we'll discuss later, suppose that there's existence of a relatively significant and stable relationship between changes in macroeconomic activity and earlier changes in this index (Vaccara and Zamowitz 1977; Auerbach 1982; Zarnowitz and Moore 1982; Diebold and Rudebusch 1989).

In addition to macroeconomic variables, awareness in investing is also required so that the investors can invest in a responsible corporate. Taking into account that various risks that may occur, would be minimized. (Paulina YurithaAmtiran, 2017). And we will see that most of the macro variables have a direct impact on stock returns. ESG investing is a way that integrates both the financial and non-financial dimensions of a stock's performance; which are usually used for evaluating the responsible side of investment. So, we'll discuss the subject matter in the spot of the Egyptian Exchange ESG Listed Companies, as a pioneer exchange in adapting sustainability. 


\section{DOI: $10.51386 / 25815946 /$ ijsms-v4i6p117}

Based on this our study aims to examine the response of stock price change percentage and macroeconomic variables which we believe are more dominant in the context of APT (Arbitrage Pricing Theory) from ESG listed companies in the Egyptian Stock Exchange.

\section{Literature Review}

The effectiveness of any corporate depends on many assessments of its overall performance and how the economic conditions impact it. So, what if this corporate was a socially responsible company would that differ or not? Today there are number of studies that defines how the National Economic performance and its variables impact the market and whether this impact is significant or insignificant. Economic condition and economic performance are two of the basics by which a country can be considered as a developed or developing country. There are many economic variables that reflect its effects on the situation of industries, markets or even the nation; and that because the economic variables affect each other, one of these variables is the stock exchange rate according to Ross's "APT" model.

\subsection{Economic performance}

Economic performance is the issue of dealing with the amount and value of money, wealth, debt, and investment in each country. "The performance of an economy is usually assessed in terms of the achievement of economic objectives"': For students of economics. i

As Onubi said that the economic performance of the construction project is an assessment between the costs incurred during construction and the expected costs before starting work, and this means carrying out the work within the agreed limits and achieving marginal profits at the same time. (Onubi, 2020)

\subsubsection{Economic performance in Egypt:}

Egypt executed a progression of changes after a cash emergency in 2016, the aftereffects of which are clear across key macroeconomic markers. Gross domestic product development rose from 5.3\% in FY 2017/18 to $5.6 \%$ in FY 2018/19, and joblessness tumbled to 7.5\%. Despite the fact that Egypt faces the difficulties of 2020 from a moderately vigorous position, lockdown measures and market disturbance have fundamentally affected the economy. In April 2020 the Ministry of Finance downsized its development figure for FY 2020/21 from $4.5 \%$ to $3.5 \%$, prior to decreasing this further to $2 \%$ in May 2020. By and by, this makes Egypt the lone Arab economy expected to encounter positive GDP development in 2020 and one of only a handful of nations worldwide not set to enter a downturn. While the full effect of the pandemic remaining parts is not yet clear, the nation has moved to alleviate the most noticeably awful impacts by boosting government ventures, and supporting independent companies and vital businesses that were antagonistically influenced by the emergency. This section contains interviews with Mohamed Maait, Minister of Finance; and Ahmed Abd El Wahab, Executive Director, General Authority for Investment and Free Zones. (Schaick, 2021)

Then at the beginning of the COVID-19 emergency, the public authority concocted a crisis reaction bundle worth LE100 billion (1.7\% of FY 2019/20 GDP). Key measures incorporate an extraordinary money related award to unpredictable labourers and the development of existing money move programs. Avoidance measures were presented as deferred charge recording and advance reimbursements, notwithstanding sponsored credit for focused areas. The Central Bank of Egypt sliced arrangement rates by 400 premise focuses to ease liquidity and empower people to get to credit at good terms. This financial development came against the background of quelled expansion, enlisted at 5.7\% in FY 2019/20, which further declined to 4.5\% during the H1-FY2020/21.

Worldwide stores remain moderately abundant, at US\$40.1 billion at end-January 2021, albeit still underneath their pre-emergency pinnacle of US $\$ 45.5$ billion. Outer records were as yet supported by settlements, bouncing back unfamiliar portfolio inflows, and outside financing, prominently from the IMF, Eurobond issuances, and an imaginative Green-bond. Development is expected to decay from 3.6\% in FY 2019/20 to 2.3\% in FY 2020/21, considering the progressing impact of the pandemic, and particularly the re-established flood in the COVID-19 cases since end-2020. The easing back of monetary action is relied upon to have unfriendly friendly ramifications.

Under the situation that the COVID-19 antibody is consistently carried out through 2021 and mid-2022, Egypt is relied upon to gradually begin recapturing its pre-pandemic development force by FY2021/22/23. A drawback situation for development over the conjecture skyline would occur if the immunization interaction 


\section{DOI: $10.51386 / 25815946 /$ ijsms-v4i6p117}

turns out to be more extended or variations of the infection bring on additional interruption, with lockdowns more than once forced. The multi-dimensional wellbeing and monetary emergency brought about by the pandemic highlights the significance of propelling the human resources plan, optimizing advanced change, and fortifying social security. The second influx of forthcoming changes, intended to release private area action and address Egypt's long-standing underlying difficulties, is critical to set out better business open doors and improve jobs. ii Egypt's economy depends basically on agribusiness, foreign trade, and tourism.

\subsection{The Arbitrage Pricing Theory:}

The Arbitrage pricing theory (APT) is a multi-factor asset pricing modeliiiand one of the primary alternatives to the Capital Asset Pricing Model (CAPM); The multi-factor model is a financial model that uses a set of different elements that are related with asset returns in order to investigate market phenomena and/or stability of asset prices. One of the multi-factor model advantages is that it could be used to explicate whether an individual security or a securities portfolio; for example, comparing two or more elements to explain relations between variables, the weight or importance of these variables and their relationship results. While constructing a multifactor model, it is hard to admit how many and which factors should be included. Also, models are judged on historical data, which may not accurately estimate future values. In multi-factor models, the different factors can be related with certain characteristics such as risk like; The Arbitrage Pricing Theory (APT) is based on the idea that by using the linear relationship between the asset's expected return and a number of macroeconomic variables that capture systematic risk that can be used to explain the expected rate of return of an asset.ivv (Gregory Connor, 1993) (EDHEC-Risk Institute, 2016)

\subsubsection{CAPM:}

As (Banz, 1981) mentioned that the capital asset pricing model (CAPM) is a one-factor model and simplest form of models' investors may want to use in order to determine the interrelationship between the systematic risk and expected return for assets. (Ezebunwa, 2015) And (Bodie, 2009) argued that CAPM has a fundamental role in the process of forming a portfolio. (Liu)

(Jack Treynor, William F. Sharpe, John Lintner, and Jan Mossin) decided in the 1960s to develop "CAPM": the capital asset pricing model, to describe the relationship between systematic risk and expected return for assets. (Perold A. F., 2004) The Capital Asset Pricing Model (CAPM); is a single-factor model that examines only one factor as the descriptive variable (the market return), so it is used to quantify the expected rate of return on an investment given:( Expected return of the investment, Risk free rate of interest, investment's sensitivity to market return and Expected return of the market). (Perold A. F., 2004).

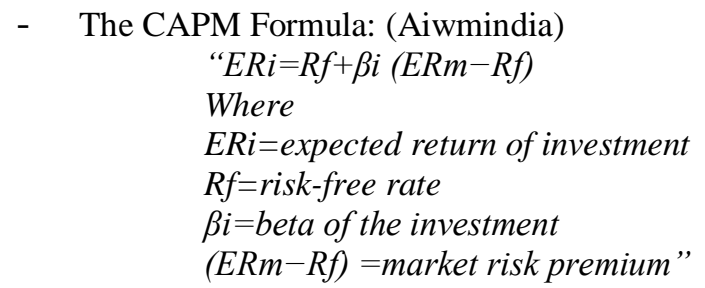

Thereafter, Ross (1976) developed the Arbitrage Pricing Theory (APT) which is an alternative to the Capital Asset Pricing Model (CAPM) that was put to overcome the late shortage while still retaining the underlying message of it, the APT is more elastic than the CAPM; Arbitrage Pricing Theory (APT) is an advanced theory of (CAPM) where, as due to APT, systematic risk is not the only factor impacting the rate of return, there are other many factors affecting the rate of return which is macroeconomic variables. the CAPM only takes into consideration one factor to capture systematic risk which is "market risk" while the APT has multiple factors, the main idea of the APT is that only a small frequency of systematic influences may affect the average returns of securities on the long term. (Richard Roll, 1980).

While "CAPM" the single model factor is used to evaluate the systematic risk of investment, the "APT" use a multifactor model and the market portfolio, to see the effect on stock returns. Roll and Ross (1980) cleared that there are three elements to study the APT in relation to the expected rate of return, which are:

i The relationship APT to return

ii Defining the correlation between residual 


\section{DOI: $10.51386 / 25815946 /$ ijsms-v4i6p117}

iii Addressing the difference between the factor structures of the various securities.

- (Benaković, 2010) suggested that despite of using one single factor "CAPM" to estimate the systematic risk of investment, APT can use a single factor, the market portfolio, and a multifactor model to measure the effect on stock returns. Although, there's one major restriction of APT is the fact that the extent of the factor or index model is unknown. Therefore, it is essential to test through statistical analysis or economic.

- According to (Leković, 2017) the equilibrium models CAPM and APT are used for setting the prices of securities that imply the existence of a price balance; in order to ignoring the problem of undervaluation and overvaluation securities. As models of capital market equilibrium, the CAPM and APT models make a contribute to understanding the relationship between return and risk and asset valuation in the capital market significantly. Both models investigate the linear relationship of return and risk and the relevance of systemic risk only. Although, the key difference lies in the fact that the CAPM model is a one-factor model, and that is the critics to the usage of the CAPM model, while the APT model is a multifactor asset valuation model.

- According to (Yunita, 2018) who found that APT was more accurate than CAPM in a comparative research (from March 2014 to March 2018), estimating the stock return of the company in Jakarta Islamic stock, is that the shares are issued by the companies whose business activities are involved in halal domains. The research result on the claimed that there is insignificant difference between the reliability of CAPM and APT methods. However, the more accurate method referring to this investigation is "APT" model because it has higher accuracy rate than CAPM.

- Due to (Gusni, 2020) whose purpose was to investigate which model of CAPM or APT is more reliable in estimating the return of sharia stocks traded in the Indonesia capital market; the result of this research referred that the APT method is more adequate and accurate to be used by investors in order to predicting their return of sharia stocks that are listed in the Jakarta Islamic Index (JII) 30.

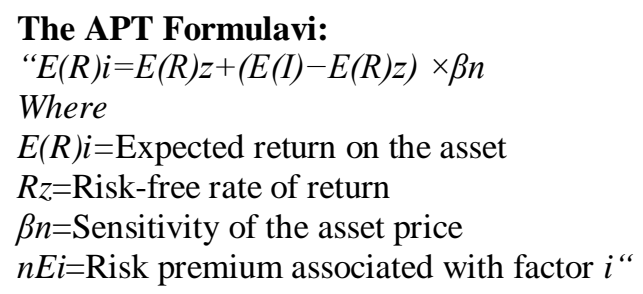

\subsubsection{Macroeconomic variables:}

(Paulina YurithaAmtiran, 2017) argued that economic data used to analyze and interpret current and future investment possibilities. It also clarifies the health of the economy. In 2014, Indonesian macroeconomic status slowed down sharply, as seen from the recession in economic growth in Indonesia with 5.21\% from 5.72\%. The limited consumption of government for their austerity budget caused this reduction and investment activity was limited due to that. As a result, inflation has increased by $8.2 \%$, on the other hand, the exchange rate decreased in value against the US dollar by $1.8 \%$, due to the US economic recovery.

- (Mazuruse, 2014) According to the "Economic factors and the stock market" which examined a set of economic state variables as systematic influences on stock market returns and their influence on asset pricing; that there's no sufficient theory would prove that the relation between financial markets and the macroeconomic is completely in one direction. It's been said that stock prices are being determined due to external forces (however they may have a feedback on the other variables). It is been admitted that all economic variables are endogenous in some conclusive sense as well as considering the stock market as endogenous, relative to other markets.

- (Roll, 2012) showed that economic indicators affect more than variables in the economy and the most is the profitability or the stock return. 


\section{DOI: $10.51386 / 25815946 /$ ijsms-v4i6p117}

- (ZobiaIsrar Ahmed, 2019) As for (Macroeconomic Factors and Equity Market of Pakistan) research which examined the economic indicators and how they affect the profitability or the stock return whether positively or negatively.

- (Pilinkus, 2010) tackled the impact of the macroeconomic indicators on the stock market index which also show us the relationship between the macroeconomic indicators and the stock market index, so we can relate it with our idea and know how they are performing.

- (Reddy, 2012) examined the impact of inflation and GDP on stock market returns in India); The economic indicators or variables accounted for $95.6 \%$ of the stock price, which means that there is a strong relationship between the economic indicators and the return.

\subsubsection{GDP:}

(Keen, 2012) mentioned that the Gross Domestic Product Growth rate is a fundamental measurement tool of economic growth demonstrating the final monetary value of all finished goods and services produced by a country within a specific period.

- (Lakonishok, Shleifer and Vishney's, 1994) Showed that stocks with a high valuation imply high growth rate in compare with fundamental ones, however these stocks have performed less than expected in the years that follows and that proves the contrarian investment strategies for.

- (John Paul Broussard, et. al, 2005) managed to be more precise and find neat differences of measuring and define the growth when they were trying to find the role of growth in long-term investment decisions and stock valuation. From a latter phase and with additional tests than used by LSV signals that growth is an essential valuation factor, and valuation measures such as earnings relative to price (E/P) and book value relative to market (B/M), are insufficient representatives for expected growth. While investors may not understand changes in growth rates and this miss-interpretation of expected growth may help explain the superiority of value versus growth strategies.

- (Andrew Ang, 2004) reached that the yield-curve model produces better out-of-sample GDP forecasts more accurate than unconstrained OLS regressions due to its performance.

- (Grace and Hotchkiss,1995) examined the relation between insurance industry performance and long-term common economic conditions. The research proved that real GDP and interest rate are negatively correlated with the underwriting profits.

- (Doumpos and Gaganis, 2012) showed that macroeconomic variables as gross domestic product (GDP) growth, inflation and income inequity impact the overall performance of firms. While (Lee, 2014) investigated upon firm specific factors and macroeconomics on firm's profitability, had proved that the velocity of economic growth has a fundamental impact on profitability.

\subsubsection{Interest Rate}

It is the amount a lender has when using assets, expressed as a percentage.

- (Park, 2011) mentioned that interest rates change too much over time, and affect the economy directly by investment, and directly the return of the companies and firms, and that's what a previous research talks about in insurance companies.

- (Jess Banhabib, 2003) studied the risks of connecting interest rates to future inflation estimates on the stabilizing features of interest-rate feedback rules. Self-fulfilling expectations have been found to cause aggregate variations as a result of such laws.

- (Samuel KwabenaObeng, 2015) investigated that exchange rate volatility, fiscal deficits, economic growth, and public sector borrowing from commercial banks all increase interest rate spreads in Ghana in the long and short run, according to the findings. In the long run, institutional quality reduces interest rate spreads, while lending interest rate volatility and risk are reduced. In the short run, monetary policy rates reduce interest rate spreads. 


\section{DOI: $10.51386 / 25815946 /$ ijsms-v4i6p117}

- (Gete, 2014) results suggested that lower interest rates stimulate the economy less in countries where acquiring development permissions is more expensive. Furthermore, the economy's response to interest rate increases is unpredictable. The longer the delay, the longer the time it will take to secure the licenses.

- (Folawewo, 2016) test the main factors of interest rate spreads by using actual loan and deposit interest rate data in order to investigate the macroeconomic and market-specific determinants of banking sector expands in 33 middle and low income (developing) countries, had tested such allegations using panel data econometric techniques. Taking in the consideration the market characteristics of banking sectors and the variables of macroeconomic instability. Surprisingly one of the results which highly touted macroeconomic policy variables was statistically insignificant "the Treasury bill rate". This insignificance refers to that any attempts by governments to make changes in their policy won't add any new or enhancements to banking sector interest rate spreads, especially if there are opposed actions and other elements constraining reductions in the spreads.

\subsubsection{Inflation Rate:}

Inflation is the rate when the value of a currency falls, so the level of prices for goods and services rises.

- (Ibrahim, 2013) There are many researches that say that there is a long run relationship between the inflation and the return, and in the last years they also said there is also a short run relationship between the inflation and return.

- (Chien-Chung Nieha, 2001) Most researchers agree that there is a negative relationship between inflation and return, because when the inflation rate increases the price of a good or service increases, so that will reduce the demand, and then reduce the sales, so the return will be affected negatively.

- (Azar, 2013) proved that there is no relationship between the inflation rate and the return.

- (Lee, 2014) investigated the importance of Macroeconomics and market factors and insurance companies' attributes related to the insurer performance. The result of the paper was that the firm performance was positively correlated to firm size, liquidity, portfolio returns, while negatively correlated to unexpected inflation.

\subsubsection{Money Supply:}

The money supply has to do with all the medium of exchange, currency circulation and other cash tools in a country's economy on a given time. It also classified as cash and deposits that can be easily liquidated.

- (WANG, 2017) examined the relationship between capital market and money market first, then they realized during the analysis that there are serial correlations; from the results that the currency movement and the stock price are correlated; for example, if the stock prices in short-term changes from the long-run equilibrium, the money supply will have a minor adjustment in order to set the stock price back to long term equilibrium.

- (Wu, 2008) examined the relationship between money supply and stock prices: applied on far east countries", it claims that there is a long-term equilibrium correlation between macroeconomic policies and stock prices proved by indicating a significant step which is the issue of spillover recognition between the macroeconomic and the stock market in: Taiwan, Hong Kong, Singapore and Korea. And as a result, stock prices aren't really influenced to the changes in either monetary or fiscal policy in the short-term.

\subsubsection{Exchange Rate:}

It is the difference between the amounts of two different currencies of two different countries. Recently where international trade is extremely important, exchange rate is fundamental determinant of any firm's profitability.

- (Tobias Olweny, 2012) claimed that the foreign exchange rate affects the stock return volatility, but it is relatively low.

- (Nucu, 2011)) Investigated the impact of the following main macroeconomic variables: (GDP, inflation rate, money supply, interest rate, and balance of payments)"; on the exchange rate of the Romanian leu versus the most important currencies during the decade 2000-2010 at when key currencies (EUR, USD) were traded. The main findings of this study were that there is an inverse relationship between the (EUR/RON) exchange rate, GDP, and money supply, and that there is a direct linkage between the (EUR/RON) exchange rate, inflation, and 


\section{DOI: $10.51386 / 25815946 /$ ijsms-v4i6p117}

interest rate. The relationship between exchange rate and balance of payment cannot be verified.

- (Oyeranti, 2019) studied the impact of exchange rate on macroeconomic aggregates: in Nigeria; The study indicates the potential correlation (whether direct or indirect) between the exchange rate and GDP change with two methods: first one is "simultaneous equations model" within a fully specified (but small) macroeconomic model, second one is "vector-autoregressive model"; according to time series data from (1970 to 2009). The investigation results imply that there is no proof of direct relation between the changes in exchange rate and GDP. But instead of that, Nigeria's economic growth has direct correlation with fiscal and monetary policies.

- (Abar, 2015) According to the research paper "Influence of Macroeconomic Variables on Exchange Rates", Exchange rates are important in because it determines the type of hedging that has to be done to minimize price fluctuations. The paper discusses the annual exchange rates and macroeconomic indicators like: relative interest rate, $\mathrm{BOP}$, inflation rates, etc., to investigate the effects they have on the economy. They discovered that the exchange rate was influenced by all macroeconomic variables unless employment and budget deficiency. But what was out of the expectations they also found out that their an important role for the investor psychological factors on the exchange rate like investor trust command over economic variables in determining exchange rate instability.

- (Yoshiro Tsutsui, 2005) examined the relation between export potency and the Japanese firms' net foreign position and how this reflects investors behavior and then stock prices; using in investigation a multi-factors model includes :(TOPIX (stock price index in Japan), call rate, the exchange rate, and other determinants reflect the traits of the firms). Main findings that were found during the research those Japanese investors importantly take into consideration the characteristics of the firm they're investing in; for example, they consider their dealings history and their position. The market efficiency was positively affected throughout the observation period the sample period which is from 1983 to 1996. Stock investors appropriately estimate the firms' foreign position.

\subsubsection{Unemployment Rate:}

(Ndzwayiba, 2020) argued that unemployment rate is the average number of workers who want to work but don't find jobs, which in return affect the economic output. It also has types differentiated as frictional, cyclical, structural, or institutional.

- (Farmer, 2015) According to "Roger E A Farmer", over the last 30 years of the macroeconomic history, the general equilibrium models in addition to indefinite equilibria were used by "the Indeterminacy School of Macroeconomics" to define the independency of beliefs in estimating macroeconomic outcomes. And he added that he made a revision on the latest enhancements on (the indeterminacy agenda and Keynesian's Theory) and he claimed that agenda needed to be updated so, he added as he described "self-fulfilling beliefs" to the Keynesian's Model in two scenarios; the first is controlled by the "investment expenditure" which is an exogenous, then implied that the only solution unemployment is by adapting the public investment instead of the private investment. The second scenario of the model is moved by "consumer confidence". If we considered the consumer confidence as exogenous then central bank involvement in the asset markets is a highly effective way of rising the employment than fiscal policy. He concluded his research with his opinion that at any scenario, the increasing in the government consumption won't be enough at the face of constantly depressed beliefs about the value of private assets in lifting the employment rate.

- (Arabaci, 2017) provided some recent empirical proofs that stand with (Farmer) claims using "threshold cointegration and asymmetric error correction models". As he added that the natural rate hypothesis is an outdated idea. So, his findings present that threshold cointegration and asymmetric error correction models can assess asymmetric dynamics between unemployment rate and the stock market. In addition to, transforming the routine of the momentum threshold autoregressive enhancements specification are highly correlated with degradations in the US economy over the last 60 years.

\subsection{ESG Investment:}

"Investing for Change" as (Landier, A., \& Nair, V.B., 2009) defined; "ESG" stands for (Environmental, Social, and Governance), It's an investment that defines the relationship between the investor and the (environmental, social, and governance) factors, and of the long-term health and stability of the market as a 


\section{DOI: $10.51386 / 25815946 /$ ijsms-v4i6p117}

whole. Responsible investment has many fields; (Ethical investment, Socially Responsible investment SRI, Sustainable investment, ESG investment, ESG integration, thematic investment, green investment). In addition to "Responsible investing," and "Sustainable investing" are master terms that refer to the integration of environmental, social, and governance aspects into investors' decisions. Investments that integrate financial return with required social or environmental impact is growing has been a demand. Those "non-financial factors" are usually used for evaluation process in order to recognize risks and growth opportunities. It's been assessed according to impacts on: environmental side (Pollution, carbon emissions...etc.), social (employee gratification), and governance (company's leadership, management, board structure...etc.).

\subsubsection{Concept history}

With early 2000s, with more aware people a set of new values have been appeared accordingly the importance of responsible investment became even clearer. So, how did it all start; the principles for responsible investment were developed by an international group of institutional investors reflecting the increasing relevance of environmental, social and corporate governance issues to investment practices. In 2005, Kofi Annan "the UN Secretary-General at then", invited a group of the world's largest institutional investors- a 20person investor group was drawn from institutions in 12 countries- to be part of the step of developing "Principles for Responsible Investment". From this initiative the Principles for Responsible Investment were ready to be launch in April 2006 at the New York Stock Exchange.vii

\subsubsection{ESG fields:}

\subsubsection{Environmental investment}

Environmental investment is a form of socially responsible investing (SRI) and type of the ESG as well, the conceptual similarity with the terms "ethical investment" and "sustain-ability investment", where investors tend to choose investments in companies that introduce or supply environmentally companionable products and services. The main criteria guiding companies' investment, as well as the ultimate goals, are the points of distinction among them. It considered as a "positive screening" in that they will be looking for business profitability as well as seeking to make a favorable and sustainable impact on the environment. Inverse with the "negative screening" used by social investors who simply look only for profitability which may affect the world in a negative way. (Lović, 2019)

\subsubsection{Socially responsible investment}

It is also known as social investment or sustainable investment; it is an investment that is considered socially responsible because of the nature of the business that the companies work in. Topics for responsible investing include social conscious investing, it can be made in individual companies with high social value, or socially conscious mutual fund, or exchange traded fund.viii

\subsubsection{Governance investment}

Governance usually used as a control technique in relation to corruption, taxes, shareholder's rights and all these internal control stuff. It's an investment activity that focuses on companies and its development; the production and discovery of alternative energy sources, the implementation of the projects of clean air and water, or other environmental projects. While giving attention to the relation between corporates and shareholders keeping transparency.ix 13

\subsubsection{Current situation:}

Nowadays Positive approaches to sustainability issues have become increasingly popular with socially conscious investors in recent years. Impact investing and the mainstreaming of environmental investing are two examples of new practices that are still evolving. With social challenges such as income and wealth disparities, climate change, waste, and corruption beginning to emerge, companies should plan to continue to discuss their effect on social issues and improve their stances in the future. More investments will be planned with these issues in mind as environmental and corporate social responsibility policies begin to bring perceived customer and investor value to businesses. $\mathrm{X}$

\subsubsection{Assessment of ESG Companies:}

(Shiller, 2013) defined ESG investing is a concept that gives attention to non-financial dimensions of a stock's performance, including the impact of the company on the environment, a social, and governance dimension.

- As a pioneer exchange in adapting sustainability principles, the Egyptian Exchange (EGX) aims to enhance 


\section{DOI: $10.51386 / 25815946 /$ ijsms-v4i6p117}

transparency in Egyptian Capital Market, and guarantee that sustainability is well adapted and exposed by listed companies. (The Egyptian Exchange, 2016)

- The index of EGX (ESG/S\&P) was launched by the Egyptian Exchange (EGX) in collaboration with Egyptian Institute of Directors (EIOD), Standard \& Poor's Financial Services LLC (S\&P), and Credit Rating Information Services of India Limited (CRISIL). According to the emerging markets EGX (ESG/S\&P) is the second index for sustainable development in after the index of "P\&S/India ESG" that was launched by India in 2008. It consists of Top 30 companies, selected out of the 100 most active companies in EGX. The criteria of selection depend on an analysis for the selected companies based on the S\&P standards. So, what is the criteria? Xi

\subsubsection{Criteria of selection:}

We didn't use these criteria but we want to address it in order to investigate the subject manner very well. - Corporate Sustainability Assessment and SAM Data Collection issues a call to many companies based on their size, county and country on an annual basis. By using of the 61 "SAM Industries", which is obtained from (GICS), in order to evaluate companies using industry-specific surveys using available corporate data, and form self-assessed scores. thatanalyze a range of financially related sustainability criteria.

- The SAM CSA Calculation process each of ESG factors are evaluated for each company regarding its sustainability activities and interests. Each ESG factor within every industry, has a different weight, and this consider every company sustainable path, in the end ESG score calculation, which is the sum of all the ESG factors. (S\&P Dow Jones Indices, 2020) mentioned that the mass of every factor is being defined according to the financial materiality of each subject to the specific industry under the SAM CSA revision every year.

\subsection{Impact of Macroeconomic Variables on ESG companies Stock Price Changes:}

(Nai-Fu Chen, 1986) argued that there is no satisfactory theory would deny that the relation between financial markets and the macroeconomic factors, it is totally in a one direction. Although, stock prices may respond to external forces especially if those stocks are ESG companies. It is apparent that all economic variables are endogenous in some ultimate sense.

ESG is being developed every day and it is more prevalent than before, so of course this will affect the economic performance of the country that has this development. It's like having a new line of investment. In the early period of the emergence of responsible investment some economies refused this type of investment because they thought that this would stop their economy and reduce their activity. Day after day, this point of view had been denied, and it had proved that responsible investment is more appropriate for each economy and county. It raises the economic performance of some countries and develops them such as Egypt and Saudi Arabia. And this is the relationship now between responsible investment and the economic performance, which we can consider as a positive relationship.

\section{Research Objectives:}

The objective behind this research is to measure the impact of The Macroeconomic Variables on Stock Price Changes Percentage for The ESG Listed Companies. And if it's consistent with the theory or contradict against it. The aim behind the research is to better understand each variable and the relationship between them as it is one of the most important topics in the green finance field today.

\section{Research Importance:}

This study will introduce a new information to help find more solutions as it relates the Macroeconomic factors affecting the stock price; as it tends to add and investigate the topic deeply at the case of "ESG Listed Companies" with providing detailed analysis and including the arbitrage pricing model.

\section{Research Gap:}

The previous literature review was very detailed and discussed mostly all the aspects in the topic "the impact of the macroeconomic variables on stock price changes for the ESG listed companies" but not all of them. The articles discussed every variable independently in details, and there were some articles that tackled two variables together; however, there was no article that tackled all the variables together or tackled the subject manner taking the "ESG listed companies" into consideration and in the spot of the arbitrage pricing model specifically. Additionally, this topic was not mentioned before in Egypt as best as we know in particular. As it's the first 


\section{DOI: $10.51386 / 25815946 /$ ijsms-v4i6p117}

research that will cover the gap and discussing all the variables and find their impact on "ESG listed companies".

6. Theoretical Framework and hypothesis: Figure 1: (Conceptual Framework)

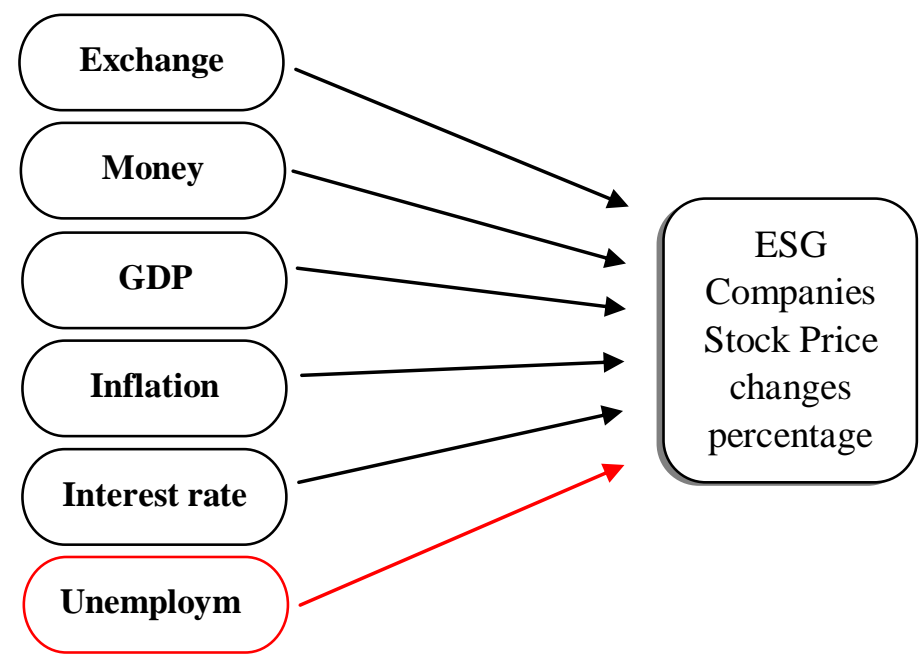

\subsection{Research Question:}

- Major research question: "To what extent the ESG Listed Companies' Stock prices respond to Macroeconomic Variables in Egypt?".

- Minor research questions are:

- “To what extent the GDP influences the ESG Listed Companies' Stock prices in Egypt?”

- "To what extent the inflation rate influences the ESG Listed Companies' Stock prices in Egypt?"

- "To what extent the interest rate influences the ESG Listed Companies' Stock prices in Egypt?"

- "To what extent the money supply influences the ESG Listed Companies' Stock prices in Egypt?"

- "To what extent the exchange rate influences the ESG Listed Companies' Stock prices in Egypt?"

\subsection{Conceptual model:}

$\gamma=\beta 0+\beta 1 \times 1+\beta 2 \times 2+\beta 3 \times 3+\beta 4 \times 4+\beta 5 \times 5+\varepsilon$

Where:

: The ESG listed companies' changes in stock price

$\beta 0$ : Constant

$\mathrm{X} 1$ : Exchange rate

X2: GDP GR

X3: Money supply

$\mathrm{X} 4$ : Interest rate

$\mathrm{X} 5$ : Inflation rate

$\varepsilon$ : Residuals

\subsection{Research hypothesis:}

- H1: There is a significant relationship between Macroeconomic variables and the ESG Listed Companies' Sock prices change percentage.

- H2: The GDP has a significant impact on the ESG Listed Companies' Stock prices change percentage.

- H3: The Inflation rate has a significant impact on the ESG Listed Companies' Stock prices change percentage.

- H4: The Interest rate has a significant impact on the ESG Listed Companies' Stock prices change percentage. 


\section{DOI: $10.51386 / 25815946 /$ ijsms-v4i6p117}

- H5: The Money supply has a significant impact on the ESG Listed Companies' Stock prices change percentage.

- H6: The Exchange rate has a significant impact on the ESG Listed Companies' Stock prices change percentage.

\section{Research Methodology:}

This chapter will focus mainly on the methods of planning and implementing of the research in order to find answers to the research questions and to support or reject the hypotheses. It will also discuss the types of the research approaches whether it is qualitative or quantitative; define the target population and the sample, the sampling size that will be used, and the sampling techniques.

\subsection{Research approach:}

This research type is explanatory; it depends mainly on providing insights through secondary data, theories and literature review :( Books, old publications, articles and industrial reports) were addressing more or less our research problem.

\subsection{Data collection:}

As it's a quantitative research depends on time series analysis measured through indicating quarterly data from January 2016 till December 2020, so the data collection instrument of this paper mainly was implemented through secondary data depends on gathering data from The Egyptian Stock Exchange "EGX" and The Central Bank of Egypt. As we've implemented our investigation on measuring the relationship between the ESG Listed Companies' Stock price change percentage as a dependent variable and Macroeconomic variables as independent variables. As we had to exclude the "Unemployment rate" due to lack of its data fit with other variables data frequencies.

\begin{tabular}{|l|l|}
\hline Explanatory Variable & Description \\
\hline $\begin{array}{l}\text { 1. Stock price change } \\
\text { percentage DV1 }\end{array}$ & $\begin{array}{l}\text { - A stock price is a price given for every share issued by a certain company } \\
\text { and it considered as a reflection of the company's value. It changes based on } \\
\text { the variety of factors in the global landscape (Macro factors) and within the } \\
\text { company itself (Micro factors). }\end{array}$ \\
\hline $\begin{array}{l}\text { 2. GDP (growth rate) } \\
\text { IV1 }\end{array}$ & $\begin{array}{l}\text { - the Gross Domestic Product Growth rate as (Keen, 2012) mentioned that is a } \\
\text { fundamental measurement tool of economic growth demonstrating the final } \\
\text { monetary value of all finished goods and services produced by a country } \\
\text { within a year. }\end{array}$ \\
\hline 3. Exchange rate IV2 & $\begin{array}{l}\text { - It measures the difference between the amounts of two different currencies } \\
\text { of two different countries. }\end{array}$ \\
\hline 4. Money supply IV3 & $\begin{array}{l}\text { - It has to do with all the medium of exchange, currency circulation and other } \\
\text { cash tools in a country's economy on a given time }\end{array}$ \\
\hline 5. Inflation IV4 & $\begin{array}{l}\text { - It is the rate when the value of a currency falls, so the level of prices for } \\
\text { goods and services rises. }\end{array}$ \\
\hline 6. Interest & $\begin{array}{l}\text { - It is the amount a lender has when using assets, expressed with a } \\
\text { percentage. }\end{array}$ \\
\hline
\end{tabular}

\subsection{Statistical Model:}

First, we will use Descriptive statistics that measures the normality specially for the dependent variable "The stock price change percentage". Second, we'll use the correlation analysis in order to estimate the relationship between the Macroeconomic variables (IVS) and the stock price change percentage of the ESG listed companies (DV). Third, we're going to use the multiple regression analysis the measures the impact of the Macroeconomic variables on the stock price change percentage of the ESG listed companies.

\section{Data analysis \& design:}

This research type is exploratory. The data analysis process is a very important procedure in any research as it supports the data obtained. The data analysis method implemented through three stages: the first descriptive statistics in order to highlight the normality of data; second, correlation matrix to measure relationships between 


\section{DOI: $10.51386 / 25815946 /$ ijsms-v4i6p117}

Volume: 4 Issue: 6

variables to estimate the strength of the relationships between variables and the third one is the regression analysis to measure the impact of macroeconomic variables on stock price change percentage.

\subsection{Descriptive statistics:}

The research covers the period from January 2016 to December 2020. The final sample consists of 300 observations. The below Table displays the descriptive statistics of the used total sample as shown below:

Table 1: (Descriptive statistics)

\begin{tabular}{|c|c|c|c|c|c|}
\hline \multicolumn{6}{|c|}{ Descriptive Statistics } \\
\hline & $\mathrm{N}$ & Mean & Std Dev & Minimum & Maximum \\
\hline IV1 & 300 & 15.92 & 3.09 & 8.88 & 18.38 \\
\hline IV2 & 300 & 3450371 & 838508.9 & 1987839 & 4920525 \\
\hline IV3 & 285 & .04 & .11 & -.09 & .27 \\
\hline IV4 & 300 & .16 & .02 & .12 & .20 \\
\hline IV5 & 300 & .01 & .01 & -.03 & .03 \\
\hline DV1 & 300 & .00 & .23 & -1.00 & .81 \\
\hline Valid N (listwise) & 301 & & & & \\
\hline Missing N (listwise) & 16 & & & & \\
\hline
\end{tabular}

Table 1 indicates that the dependent variable (DV1) its standard deviation is less than one which indicate that it's normally distributed.

8.2. Correlation:

The correlation analysis is a useful type of analysis when a researcher wants to establish if there are possible connections between variables.

Table 2: (Correlation analysis)

\begin{tabular}{|ll|r|r|r|r|r|r|}
\hline & & \multicolumn{1}{|c|}{ IV1 } & \multicolumn{1}{c|}{ IV2 } & \multicolumn{1}{c|}{ IV3 } & \multicolumn{1}{c|}{ IV4 } & \multicolumn{1}{c|}{ IV5 } & \multicolumn{1}{c|}{ DV1 } \\
\hline IV1 & Pearson Correlation & 1.000 & .468 & .336 & .513 & .036 & .097 \\
& Sig. (2-tailed) & & .000 & .000 & .000 & .535 & .093 \\
& $\mathrm{~N}$ & 300 & 300 & 285 & 300 & 300 & 300 \\
\hline IV2 & Pearson Correlation & .468 & 1.000 & .141 & -388 & -.369 & .243 \\
& Sig. (2-tailed) & .000 & & .017 & .000 & .000 & .000 \\
& $\mathrm{~N}$ & 300 & 300 & 285 & 300 & 300 & 300 \\
\hline IV3 & Pearson Correlation & .336 & .141 & 1.000 & -.015 & .067 & .180 \\
& Sig. (2-tailed) & .000 & .017 & & .798 & .259 & .002 \\
& $\mathrm{~N}$ & 285 & 285 & 285 & 285 & 285 & 285 \\
\hline IV4 & Pearson Correlation & .513 & -.388 & -.015 & 1.000 & .169 & -.073 \\
& Sig. (2-tailed) & .000 & .000 & .798 & & .003 & .208 \\
& $\mathrm{~N}$ & 300 & 300 & 285 & 300 & 300 & 300 \\
\hline IV5 & Pearson Correlation & .036 & -.369 & .067 & .169 & 1.000 & .062 \\
& Sig. (2-tailed) & .535 & .000 & .259 & .003 & & .284 \\
& $\mathrm{~N}$ & 300 & 300 & 285 & 300 & 300 & 300 \\
\hline DV1 & Pearson Correlation & .097 & .243 & .180 & -.073 & .062 & 1.000 \\
& Sig. (2-tailed) & .093 & .000 & .002 & .208 & .284 & \\
& $\mathrm{~N}$ & 300 & 300 & 285 & 300 & 300 & 300 \\
\hline
\end{tabular}

And as shown above at Table 2; the correlation between the independent variables mostly weak (less than 70\%), only one variable as it shown is $79 \%$. And the correlation between the dependent variables and the independent tends to be strong, except (IV4). 


\section{DOI: $10.51386 / 25815946 /$ ijsms-v4i6p117}

\subsection{Regression Analysis:}

Regression analysis is a related technique to assess the relationship between the response or dependent variable "Y" and one or more risk factors or confounding variables which is also called the explanatory or independent variables "X".

The following tables represent the result of the first regression model where the ESG Listed Companies' Stock prices change percentage is the dependent variable "Y" and the five macroeconomic variables which are the independent variables "XS".

Table 3: (Regression analysis)

\begin{tabular}{|l|r|r|r|}
\multicolumn{9}{c}{ Model Summary (DV1) } \\
\begin{tabular}{|r|r|r|r|}
\hline R & R Square & Adjusted R Square & Std. Error of the Estimate \\
\hline .41 & .16 & .15 & .22 \\
\hline
\end{tabular}
\end{tabular}

From Table 3, It's obviously that all the R2 equal $16 \%$ which is a low value which indicates that the independent variables explaining only $16 \%$ of the dependent variable while the rest $84 \%$ other variables explaining the dependent variable.

Table 4: (ANOVA test)

ANOVA (DV1)

\begin{tabular}{|l|r|r|r|c|c|}
\hline & Sum of Squares & \multicolumn{1}{c|}{ df } & Mean Square & $\mathrm{F}$ & Sig. \\
\hline Regression & 2.64 & 5 & .53 & 10.98 & .000 \\
Residual & 13.42 & 279 & .05 & & \\
Total & 16.06 & 284 & & & \\
\hline
\end{tabular}

ANOVA test from Table 4 examines whether the model is significant or not. Here, the significance level is 0.000 which is less than the acceptable significance level of 0.05 .

\section{Table 5: (Coefficients table)}

Coefficients (DV1)

\begin{tabular}{|c|c|c|c|c|c|}
\hline & \multicolumn{2}{|c|}{ Unstandardized Coefficients } & \multirow{2}{*}{$\begin{array}{c}\text { Standardized Coefficients } \\
\text { Beta }\end{array}$} & \multirow[b]{2}{*}{$\mathrm{t}$} & \multirow[b]{2}{*}{ Sig. } \\
\hline & B & Std. Error & & & \\
\hline (Constant) & -.98 & .19 & & -5.02 & .000 \\
\hline IV1 & -.05 & .01 & -5 & -4.23 & .000 \\
\hline IV2 & .00 & .00 & & 6.13 & .000 \\
\hline IV3 & .50 & .13 & & 3.79 & .000 \\
\hline IV4 & 5.14 & 1.24 & 5 & 4.15 & .000 \\
\hline IV5 & 4.86 & 1.11 & & 4.38 & .000 \\
\hline
\end{tabular}

The Econometric model parameters result:

$\gamma=-0.98-0.05 \times 1+0.5 \times 3+5.14 \times 4+4.86 \times 5+\varepsilon$

Where:

$\gamma$ : The ESG listed companies' changes in stock price

$\mathrm{X} 1$ : Exchange rate

X3: Money supply

$\mathrm{X} 4$ : Interest rate

X5: Inflation rate

$\varepsilon$ : Residuals

\section{Discussion:}

- The main results of the analysis found that the descriptive statistics indicated that the standard deviation of the DV is less than one which indicate that it's normally distributed. 


\section{DOI: $10.51386 / 25815946 /$ ijsms-v4i6p117}

- According to the correlation matrix, there is a significant relationship between Macroeconomic variables and the ESG Listed Companies' Stock prices change percentage.

- Time series regression analysis conducted that $\beta 0$ which is the $y-$ intercept is with a negative sign (=-0.98) and this simply means that the expected value of the dependent variable will be less than zero. In addition to finding macroeconomic variables coefficient respectively as; Exchange rate coefficient's, also with a negative sign (0.05 ) which is a negative impact on stock price changes. That also means that each company's share is listed on the ESG is not really sensitive to Exchange rate as in the overall coefficient value smaller than 1. Money supply coefficient equals zero which has no impact on stock price changes. GDP coefficient has a positive impact which is equal (0.5) but the overall is still lower than 1 . Interest rate coefficient has positive and the most powerful impact on the dependent variable as it equals (5.14) and this indicates that the volatility of the interest during the period from November 2016 up till the end of 2019. And last but not least the Inflation rate coefficient which also has a positive impact and considered as the second high value impact on the dependent variable with (4.86). Where the same regression analysis run on a data in different time periods and it showed the regression exceeding (16\%). (Awd, 2015) (Rageb, 2018)

\section{Conclusion:}

This research is measuring the Macroeconomic variables impact on the ESG listed companies' stock price changes in order to find and display the difference of those companies from conventional ones. And the findings showed that they're less influenced by the Macroeconomic variables than the conventional companies; taking into account that in a similar research papers when these analyses were measuring the impact of Macroeconomic variables on conventional EGX 30 companies (not ESG companies) it indicated that they have high level of risk than the ESG listed companies, this indicates that the ESG companies have low risk level as they're more influenced by their performance more than the Macroeconomic variables. In addition to reflecting the validity of ESG listed companies' measurements' Dow jones and Standard\& Poor.

Our research main findings showed that both Interest and Inflation rates had the highest impact on the stock prices percentage changes and this indicates that those variables having significant impact on the performance of those companies' stocks and may also impact their financial performance. Finally, we advise those companies to keep a close eye "follow up" in order to predict or forecast both inflation and interest rates specifically from the other variables.

\section{Implications, limitations and recommendations:}

\subsection{Implications:}

Our study main findings shows that the ESG companies are consistent with sustainable corporates where the other researches findings have an evidence for different developed and developing countries which are less influenced by Macroeconomic variables volatility "risks" than the conventional companies.

\subsection{Limitations:}

We didn't have the opportunity to compare ESG companies with identified sustainable companies such as SEKEM holding because it isn't a listed company in the Egyptian Stock Exchange. And there aren't enough sustainable companies to be compared with in order to apply statistical model.

\subsection{Recommendations:}

- All the companies within Egypt have to work hard to transform towards the ESG practices as from the results we have investigated it has low level of risks. In addition to having the most adequate awareness level regarding the Macroeconomic variables and its impacts specially Interest and inflation rates.

- We also recommend taking a guide like Egypt 2030 Sustainable Development Vision Strategy; we believe that many companies could have a beneficial transformation process if they follow its principles and taking the path through economic prosperity, environmentally friendly practices and social justice, seeking reviving the development of Egypt.

- Authorization of issuing green reports, this means normalization of issuing reports regarding the sustainable and corporate social responsibility reports to review the ESG practices and the transformation of conventional companies if any, of course attached with sustainable and ESG indicators. Companies can enhance their trust if 


\section{DOI: $10.51386 / 25815946 /$ ijsms-v4i6p117}

Volume: 4 Issue: 6

November to December 2021

https://www.ijsmsjournal.org

they are transparent about the way they deal with ESG matters.

\section{References}

[1] Abar, R. R. (2015). Influence of Macroeconomic Variables on Exchange Rates. Journal of Economics, Business and Management. From http://joebm.com/papers/194-W10044.pdf

[2] Ahmed, M. (2015). What do you know about EGX ESG/S\&P index? Daily news egypt. From https://dailynewsegypt.com/2015/10/24/what-do-you-know-about-egx-esgsp-index/

[3] Aiwmindia. (n.d.). Multifactor Risk and Return Models. From https://www.aiwmindia.com/wp-content/uploads/2018/09/Chapter11.pdf

[4] Andrew Ang, M. P. (2004). WHAT DOES THE YIELD CURVE TELL US ABOUT GDP GROWTH? NATIONAL BUREAU OF ECONOMIC RESEARCH. From https://www.nber.org/system/files/working_papers/w10672/w10672.pdf

[5] Arabaci, O. (2017). Testing for cointegration with threshold effect between unemployment and stock prices. doi: $10.1080 / 13504851.2017 .1355529$

[6] Awd, M. M. (2015). Test of TheArbritrage Pricing Theory in the Egyptian Stock Exchange

[7] Azar, S. A. (2013). The Spurious Relation between Inflation Uncertainty and Stock Returns: Evidence from the U.S.

[8] Benaković, D. \&. (2010). "Do macroeconomic factors matter for stock returns? Evidence from estimating a multifactor model on the Croatian market.".

[9] Chien-Chung Nieha, C.-F. L. (2001). Dynamic relationship between stock prices and exchange. From http://mail.tku.edu.tw/niehcc/pdf/nl(2001-qref)s\&f(g-7).pdf

[10] EDHEC-Risk Institute. (2016). Multi-Dimensional Risk and Performance Analysis for Equity Portfolios.

[11] Egypt: Economy. (n.d.). From https://globaledge.msu.edu/countries/egypt/economy

[12] Ezebunwa, J. n. (2015). Review of the Capital Asset Pricing Model (CAPM) with a view to ascertaining or disputing the claim.

[13] Farmer, R. E. (n.d.). The importance of beliefs in shaping macroeconomic outcomes. doi:10.1093/oxrep/graa041

[14] Folawewo, D. T. (n.d.). MACROECONOMIC AND MARKET DETERMINANTS OF BANKING SECTOR INTEREST RATE SPREADS: EMPIRICAL EVIDENCE FROM LOW AND MIDDLE INCOME COUNTRIES. From https://www.researchgate.net/profile/David-

Tennant/publication/251228439_MACROECONOMIC_AND_MARKET_DETERMINANTS_OF_B ANKING_SECTOR_INTERE ST_RATE_SPREADS_EMPIRICAL_EVIDENCE_FROM_LOW_AND_MIDDLE_INCOME_COUNTRIES/links/541053b80cf2d8 daaad38a36/MACROECONOMIC-AND

[15] Gete, P. (2014). Dealing with Construction Permits, Interest Rate Shocks and Macroeconomic Dynamics. From https://www.worldbank.org/content/dam/doingBusiness/media/Miscellaneous/Conference2014/2014-GETE-permits-interest-rate--macro-dynamics.pdf

[16] Gregory Connor, R. A. (1993). The Arbitrage Pricing Theory and Multifactor Models of Asset Returns.

[17] Gusni, G. S. (2020). Do CAPM or APT is Better in Predicting Sharia Stock Return? Solid State Technology.

[18] Ibrahim, T. M. (2013, Februray). THE RELATIONSHIP BETWEEN STOCK RETURN AND INFLATION IN NIGERIA. From https://www.researchgate.net/ 25

[19] Jess Banhabib, S. S.-G. (2003). INTEREST-RATE SMOOTHINGAND MACROECONOMIC INSTABILITYBACKWARD-LOOKING $\begin{array}{lllll}\text { INTEREST-RATE RULES,NATIONAL BUREAU OF } & \text { ECONOMIC RESEARCH. From }\end{array}$ https://www.nber.org/system/files/working_papers/w9558/w9558.pdf

[20] John Paul Broussard, D. M. (2005). The Role Of Growth In Long Term Investment Returns. doi:10.19030/jabr.v21i1.1503

[21] Keen, J. M. (2012). Does GDP measure growth in the economy or simply growth in the money supply? From https://www.researchgate.net/publication/230608947_Does_GDP_measure growth_in the economy_or_simply growth_in the mo neysupply\#: :text=Gross\%20Domestic\%20Product(GDP)\%20is\%20an\%20internationally\%20used\%20measurement\%20of,period.

[22] Lee, C.-Y. (2014). THE EFFECTS OF FIRM SPECIFIC FACTORS AND MACROECONOMICS ON PROFITABILITY OF PROPERTY-LIABILITY INSURANCE INDUSTRY IN TAIWAN. Asian Economic and Financial Review. From http://www.conscientiabeam.com/pdf-files/eco/3/aefr-2014-4(5)-681-691.pdf

[23] Liu, T. Z. (n.d.). Empirical study on CAPM model on China stock market. 


\section{DOI: $10.51386 / 25815946 /$ ijsms-v4i6p117}

[24] Lović, S. (2019). Environmental Investments. doi:10.1007/978-3-319-71063-1_67-1

[25] Magda Kandil, N. D. (2008). A comparative analysis of exchange rate fluctuations and economic activity: The cases of Egypt and Turkey. From https://www.researchgate.net/publication/227429243_A___comparative_analysis_of_exchange_rate _fluctuations_and_economic_activity_The_cases_of_Egypt_and_Turkey

[26] Mazuruse, P. (2014). Canonical correlation analysis: Macroeconomic variables versus stock returns. From https://ideas.repec.org/a/eme/jfeppp/v6y2014i2p179-196.html

[27] Nai-Fu Chen, R. R. (1986). Economic Forces and the Stock Market. The Journal of Business.

[28] Ndzwayiba

$$
\text { A. (2020). }
$$

What

Is

Unemployment.From https://www.researchgate.net/publication/344641992_What_Is_Unemployment\#: :text=\%EF\%82\%B7Unemployment\%20occurs\%2 0when\%20workers, may\%20signal\%20an\%20overheated\%20economy.

[29] Nucu, A. E. (2011). The Relationship between Exchange Rate and Key Macroeconomic Indicators. Case Study: Romania. The Romanian Economic Journal . From http://www.rejournal.eu/sites/rejournal.versatech.ro/files/issues/2011-09-02/559/je4120nucu.pdf

[30] Onubi, H. O. (2020, June 18). Effect of green construction on project's economic performance. Effect of green construction on project's economic performance.

[31] Oyeranti, D. E. (2019). Exchange Rate and Macroeconomic Aggregates in Nigeria. From https://www.researchgate.net/publication/337717552_Exchange_Rate_and_Macroeconomic_Aggregates_in_Nigeria

[32] Park, J. \&. (2011). Interest rate sensitivity of US property/liability insurer stock returns.

[33] Paulina YurithaAmtiran, R. I. (2017). Macroeconomic factors and stock returns in APT framework. International Journal of Economics and Management 11(1):197-206.

[34] Perold, A. F. (2004). The Capital Asset Pricing Model. JOURNAL OF ECONOMIC PERSPECTIVES.

[35] Perold, A. F. (2004). The Capital Asset Pricing Model. Journal of Economic Perspectives.

[36] Pilinkus, D. (2010). Macroeconomic indicators and their impact on stock market performance in the short and long run: The case of the baltic states. From https://www.tandfonline.com/doi/abs/10.3846/tede.2010.1926

[37] Rageb, M. (2018). Test of the arbritrage pricing theory in the financial markets applied on the Egyptian Stock Exchange.

[38] Reddy, L. (2012). IMPACT OF INFLATION AND GDP ON STOCK MARKET RETURNS IN INDIA.

[39] Richard Roll, S. A. (1980). An Empirical Investigation of the Arbitrage Pricing Theory. The Journal Of Finance.

[40] Robert D. Gay, J. (2016). Effect Of Macroeconomic Variables On Stock Market Returns For Four Emerging Economies: Brazil, Russia, India, And China.

[41] Roll, N.-F. c. (2012). Economic factors and the stock market. From http://fdjpkc.fudan.edu.cn/_upload/article/files/3f/58/2bfaa4934d989d5a49fbaf456e60/544452370-cb1c-4a75-8c2b-5322ee3e2f78.pdf

[42] S\&P Dow Jones Indices. (2020). S\&P DJI ESG Score. S\&P Dow Jones Indices. From https://www.spglobal.com/spdji/en/documents/methodologies/methodology-sp-dji-esg-score.pdf

[43] Samuel KwabenaObeng, D. S. (2015). Macroeconomic determinants of interest rate spreads in Ghana. From https://www.emerald.com/insight/content/doi/10.1108/AJEMS-12-2015-0143/full/html

[44] Schaick, H. v. (2021). Next steps: Where do Egyptian business leaders see things heading in 2021? Oxford Business Group.

[45] Springborg, R. (2017, July). Egypt's Economic Transition: Challenges and Prospects. From https://doi.org/10.4000/poldev.2277

[46] Stanisic, M. L. (2018). Capital Asset Pricing Model versus Arbitrage Pricing Theory.

[47] The Egyptian Exchange. (2016). Model Guidance for Reporting on. From https://www.egx.com.eg/getdoc/98b4f610-5544-4f93-a36e636d3baf8f45/EGX-Model-Guidance-on-ESG_en-11-10-2016.aspx

[48] Tobias Olweny, K. O. (2012). THE EFFECT OF MACRO-ECONOMIC FACTORS ON STOCK RETURN VOLATILITY IN THE NAIROBI STOCK EXCHANGE, KENYA.

[49] WANG, J.-p. (2017). Money Supply and Stock Price in China. doi:10.12783/dtetr/imeia2016/9323

[50] wu, M.-W. L.-c. (2008). The Relationship between Money Supply and Stock Prices. doi: 10.1109/ICICIC.2008.568

[51] Yoshiro Tsutsui, T. H. (2005). Exchange rate and stock prices in Japan. From 


\section{DOI: $10.51386 / 25815946 /$ ijsms-v4i6p117}

Volume: 4 Issue: 6

https://www.researchgate.net/publication/24070880_Exchange_rate_and_stock_prices_in_Japan

[52] Yunita, I. (2018). Analysis and Accuracy Level Comparison Between Capital Asset Pricing Model (CAPM) and Arbitrage Pricing Theory (APT) In Determining the Expected Return. doi:10.29322/IJSRP.8.5.2018.p7761

[53] ZobiaIsrar Ahmed, K. M. (2019). Macroeconomic Factors and Equity Market of Pakistan: Evidence from Bound Testing Technique. researchgate.

\section{Also used:}

[54] https://www.economicsonline.co.uk/

[55] https://www.worldbank.org/en/country/egypt/overview

[56] https://www.investopedia.com/terms/a/apt.asp

[57] https://www.investopedia.com/terms/m/multifactor-model.asp

[58] https://www.investopedia.com/terms/a/apt.asp

[59] https://www.investopedia.com/terms/a/apt.asp

[60] https://www.intelligenthq.com/united-nations-6-principles-responsible-investment/

[61] https://www.investopedia.com/

[62] https://www.nordea.com/en/what-is-esg

[63] https://www.thebalance.com/a-short-history-of-socially-responsible-investing-3025578

[64] https://dailynewsegypt.com/2015/10/24/what-do-you-know-about-egx-esgsp-index/ 